\title{
Bogaty świat ryboprzełączników
}

\section{Dr Piotr Machtel ${ }^{\varpi}$}

Instytut Chemii Bioorganicznej Polskiej Akademii Nauk, ul. Noskowskiego 12/14, 61-704 Poznań

https://doi.org/10.18388/pb.2020_331

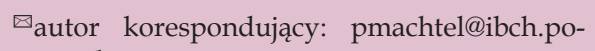
znan.pl

Słowa kluczowe: ryboprzełączniki, bakterie, regulacja ekspresji genów, transkrypcja

Wykaz stosowanych skrótów: AdoCbl - adenozylokobalamina; AqCbl - akwakobalamina; c-di-GMP - cykliczny diguanozynomonofosforan; FMN - mononukleotyd flawinowy; GlcN-6-P - glukozamino-6-fosforan; MRSA - odporne na metycylinę szczepy Staphylococcus aureus (ang. methicyllin-resistant Staphylococcus aureus); ORF - otwarta ramka odczytu; PreQ1 - prekweozyna 1, PRPP - pirofosforan fosforybozylu; SAH - S-adenozylohomocysteina; SAM - S-adenozynometionina; SD - sekwencja Shine-Dalgarno; TPP - pirofosforan tiaminy; UTR - region nieulagający translacji (ang. untranslated region); VEGF - czynnik wzrostu śródbłonka naczyniowego A (ang. vascular endothelial growth factor)

\section{STRESZCZENIE}

$\mathbf{N}$ ieustannie zmieniające się środowisko wymaga od bakterii szybkiej i zdecydowanej odpowiedzi na poziomie komórkowym. Mając do dyspozycji jedynie zasoby jednej komórki, bakterie wykształciły najróżniejsze mechanizmy kontroli ekspresji genów. Wśród nich szczególne miejsce zajmują ryboprzełączniki, sekwencje występujące w transkryptach, mające zdolność bezpośredniego wiązania niskocząsteczkowych metabolitów i wywoływania odpowiedzi regulatorowej. W niniejszej publikacji został przedstawiony aktualny stan wiedzy na temat ryboprzełączników uwzględniając między innymi: mechanizmy działania ryboprzełączników, ich budowa i różnorodność oraz występowanie. A także historia ich odkrycia na początku XXI wieku, oraz aktualne badania, mogące w przyszłości znaleźć praktyczne zastosowania.

\section{WPROWADZENIE}

Zdolność do reagowania na zmieniające się warunki życia poprzez regulację ekspresji genów jest fundamentalna dla przetrwania wszystkich żywych organizmów, z bakteriami na czele. Zróżnicowanie mechanizmów regulatorowych pozwala w precyzyjny i dynamiczny sposób reagować na wszelkie zmiany $\mathrm{w}$ środowisku naturalnym, poprzez wyciszenie bądź aktywację ekspresji poszczególnych genów i biosyntezę wyspecjalizowanych białek. Szeroki repertuar wyrafinowanych mechanizmów kontroli ekspresji genów wykorzystuje białka. Wyjątkowym mechanizmem są ryboprzełączniki (ang. riboswitches). Są to silnie ustrukturyzowane domeny mRNA, zdolne do bezpośredniego wiązania niskocząsteczkowych metabolitów, co w konsekwencji prowadzi do rearanżacji struktury drugorzędowej RNA i zmiany poziomu ekspresji danego genu w układzie cis. Kamienie milowe w historii odkrycia ryboprzełączników przedstawia Tabela 1.

\section{RÓŻNORODNOŚĆ I WYSTĘPOWANIE RYBOPRZEŁĄCZNIKÓW}

Do dziś odkrytych i eksperymentalnie potwierdzonych jest około 45 różnych klas ryboprzełączników, ze względu na strukturę oraz wiązany przez nie ligand (Tabela 2). Dlatego też niektóre ryboprzełączniki oddziałujące z tym samym ligandem mogą należeć do różnych klas, jak to ma miejsce w przypadku ryboprzełącznika SAM. Do tej pory poznano sześć różnych klas ryboprzełącznika SAM oraz SAM-SAH [32]. Z drugiej zaś strony istnieją ryboprzełączniki o identycznej strukturze różniące się zaledwie jednym nukleotydem w sekwencji aptameru, co wystarczy by całkowicie zmienić specyficzność względem ligandu. Takim przykładem może być ryboprzełącznik guaninowy, który oddziałuje z trzema nukleotydami aptameru: U22, U51, C74, natomiast substytucja C74>U74 powoduje przełączenie specyficzności z guaninę na adeninę [35]. Metabolity, które są rozpoznawane przez poszczególne ryboprzełączniki należą do wielu grup związków chemicznych, takich jak koenzymy (w tym witaminy i ich pochodne), nukleotydy i ich pochodne, cząsteczki sygnałowe, jony, czy też aminokwasy.

Klasy ryboprzełączników różnią się istotnie zarówno frekwencją jak i występowaniem filogenetycznym. Najczęstszym i najpowszechniejszym ryboprzełącznikiem, obecnym w niemal wszystkich liniach bakterii jest ryboprzełącznik TPP. Bioinformatyczna analiza wykazała obecność w metagenomach bakteryjnych niemal 16700 różnych reprezentantów ryboprzełącznika TPP [24]. Bywają też klasy ryboprzełączników niezwykle rzadkie, jak choćby ryboprzełącznik 2' dG-I, obecny jedynie w czterech kopiach, wyłącznie u bakterii Mesoplasma florum [49]. Zróżnicowane jest także wykorzystywanie ryboprzełączników przez różne grupy bakterii. Typ Firmicutes wykorzystuje je bardzo powszechnie, z 13500 reprezentantami należącymi do niemal wszystkich znanych klas ryboprzełączników, natomiast $\mathrm{w}$ genomach takich bakterii jak Chlamydiae ryboprzełączniki, 
Tabela 1. Historia odkrycia ryboprzełączników - kamienie milowe.

\begin{tabular}{|clll}
\hline Rok & Odkrycie & Odkrywcy & Referencje \\
\hline 1960 & Działanie operonu laktozowego kontrolowanego białkiem represora & Jacob F., Jacques Monod. & [1] \\
\hline 1974 & Pierwsza struktura drugorzędowa RNA & Gralla J., Steitz J., Crothers D. & [2] \\
\hline 1981 & Zjawisko ateunacji u bakterii & Yanofsky C. \\
\hline 1982 & Pierwsze funkcjonalne RNA - Rybozymy & Cech T., Altman S. & Szostak J., Gold L. \\
\hline 1990 & Zsyntetyzowanie pierwszych aptamerów & Kadner J. \\
\hline 1978 & Hamowanie biosyntezy witamin, przez produkty końcowe ich szlaków metabolicznych & [6,7] \\
\hline 1996 & Udział niekodujących fragmentów mRNA w wiązaniu ligandów & Webb E., Downs D. \\
\hline 2001 & Zmiany strukturalne pod wpływem wiązania ligandu oraz regulacja ekspresji genów & Ravnum S., Andersson D. & [12] \\
\hline 2002 & Pierwszy ryboprzełącznik & Ronald Breaker i & [10,11] \\
\hline 2004 & Pierwsza struktura krystaliczna ryboprzełącznika & Batey R., Serganov A.
\end{tabular}

jako element regulatorowy, występują niezwykle rzadko zaledwie 8 reprezentantów należących do dwóch klas.

Ryboprzełączniki w przeważającej większości występują u bakterii, jednak niektóre klasy są także charakterystyczne dla innych domen życia. U Archea licznie występuje ryboprzełącznik TPP oraz mniej licznie - fluorkowy. Do 2013 roku uważano, że na tym zamyka się lista ryboprzełączni- ków u archeonów [64], jednak okazało się, że sporadycznie możemy znaleźć ryboprzełączniki wiążące takie ligandy jak: FMN, $\mathrm{Mg}^{2+}-\mathrm{I}$ i guanidynowy-II. Ryboprzełącznik TPP jest także jedynym znanym ryboprzełącznikiem występującym u eukariotów, zwłaszcza w królestwie roślin i grzybów. 72 takie sekwencje zidentyfikowano u grzybów (np. Neurospora crassa, Aspergillus oryzae), 23 u roślin wyższych Tabela 2. Lista znanych klas ryboprzełączników.

\begin{tabular}{|c|c|c|c|c|c|}
\hline $\mathrm{Nr}$ & Grupa & Klasa & Ligand & Reprezentanci & Referencje \\
\hline 1 & & TPP & Pirofosforan Tiaminy (TPP, B1) & 16690 & {$[15]$} \\
\hline 2 & & $\mathrm{AboCbl}$ & Adenozylokobalamina (AdoCbl, B12) & 14336 & {$[13]$} \\
\hline 3 & & $\mathrm{AqCbl}$ & Akwakobalamina (AqCbl) & 582 & [25] \\
\hline 4 & & SAM-I & S-adenozylometionina (SAM) & 6749 & {$[26]$} \\
\hline 5 & & SAM-IV & S-adenozylometionina (SAM) & 732 & {$[27]$} \\
\hline 6 & & SAM-I/IV & S-adenozylometionina (SAM) & 1184 & {$[28]$} \\
\hline 7 & & SAM-II & S-adenozylometionina (SAM) & 6095 & [29] \\
\hline 8 & & SAM-V & S-adenozylometionina (SAM) & 982 & {$[30]$} \\
\hline 9 & & SAM-III & S-adenozylometionina (SAM) & 936 & {$[31]$} \\
\hline 10 & Koenzymy & SAM-VI & S-adenozylometionina (SAM) & 17 & [32] \\
\hline 11 & & SAM/SAH & $\begin{array}{l}\text { S-adenozylometionina (SAM), } \\
\text { S-adenozylohomocysteina(SAH) }\end{array}$ & 139 & {$[28]$} \\
\hline 12 & & SAH & S-adenozylohomocysteina (SAH) & 926 & [33] \\
\hline 13 & & FMN & Mononukleotyd flawinowy (FMN, B2) & 5544 & [34] \\
\hline 14 & & FMN Var & $\begin{array}{l}\text { Analog mononukleotydu } \\
\text { flawinowego (FMN, B2) }\end{array}$ & 2 & [35] \\
\hline 15 & & THF-I & Tetrahydrofolian (THF) & 1433 & {$[36]$} \\
\hline 16 & & THF-II & Tetrahydrofolian (THF) & 86 & [37] \\
\hline 17 & & Moco & Kofaktor molibdenowy (Moco) & 1021 & {$[38]$} \\
\hline 18 & & Wco & Kofaktor wolframowy (Wco, Tuco) & 715 & {$[38]$} \\
\hline
\end{tabular}




\begin{tabular}{|c|c|c|c|c|c|}
\hline 19 & \multirow{6}{*}{$\begin{array}{l}\text { Cząsteczki } \\
\text { sygnałowe }\end{array}$} & ZTP & $\begin{array}{l}\text { Rybonukleotyd aminoimidazolokarboksyamidu } \\
\text { (ZTP, AICAR) }\end{array}$ & 2229 & [39] \\
\hline 20 & & c-di-GMP-I & 5'-3'-cykliczny di-GMP (c-di-GMP) & 6414 & [40] \\
\hline 21 & & c-di-GMP-II & 5'-3'-cykliczny di-GMP (c-di-GMP) & 1147 & {$[41]$} \\
\hline 22 & & c-AMP-GMP & 5'-3'-cykliczny AMP-GMP (c-AMP-GMP) & 107 & [42] \\
\hline 23 & & c-di-AMP & 5'-3'-cykliczny di-AMP (c-di-AMP) & 3098 & [43] \\
\hline 24 & & ppGpp & Tetrafosforan Guanozyny (ppGpp) & 105 & {$[44]$} \\
\hline 25 & \multirow{3}{*}{ Aminokwasy } & Glutaminowy & Glutamina $(G \ln , Q)$ & 1567 & {$[45]$} \\
\hline 26 & & Glicynowy & Glicyna (Gly, G) & 7516 & {$[46]$} \\
\hline 27 & & Lizynowy & Lizyna (Lys, K) & 4114 & {$[47]$} \\
\hline 28 & \multirow{9}{*}{$\begin{array}{l}\text { Nukleotydy i } \\
\text { pochodne }\end{array}$} & Guaninowy & Guanina (G) & 2334 & {$[48]$} \\
\hline 29 & & Adeninowy & Adenina (A) & 99 & [48] \\
\hline 30 & & $2^{\prime}-\mathrm{dG}-\mathrm{I}$ & 2'-deoksyguanozyna (2'-dG) & 4 & [49] \\
\hline 31 & & 2'-dG-II & $2^{\prime}$-deoksyguanozyna $\left(2^{\prime}-\mathrm{dG}\right)$ & 12 & [35] \\
\hline 32 & & $\operatorname{PreQ}_{1}$-I & Prekweozyna $_{1}\left(\right.$ PreQ $\left._{1}\right)$ & 2387 & {$[50]$} \\
\hline 33 & & PreQ $_{1}$-II & Prekweozyna $_{1}($ PreQ1) & 263 & {$[51]$} \\
\hline 34 & & PreQ $_{1}$-III & Prekweozyna $_{1}\left(\right.$ PreQ1) $_{1}$ & 86 & {$[52]$} \\
\hline 35 & & PRPP & Pirofosforan fosforybozylu (PRPP) & 257 & {$[53]$} \\
\hline 36 & & $(\mathrm{~d}) \mathrm{ADP} /(\mathrm{d}) \mathrm{CDP}$ & $\begin{array}{l}\text { di-fosforany nukleozydów: } \\
\text { ADP, dADP, CDP, dCDP }\end{array}$ & 46 & {$[54]$} \\
\hline 37 & \multirow{5}{*}{ Jony } & $\mathrm{Mg}^{2+}-\mathrm{I}$ & Kation magnezu $\left(\mathrm{Mg}^{2+}\right)$ & 971 & [55] \\
\hline 38 & & $\mathrm{Mg}^{2+}-\mathrm{II}$ & Kation magnezu $\left(\mathrm{Mg}^{2+}\right)$ & 101 & [56] \\
\hline 39 & & $\mathrm{Ni}^{2+} / \mathrm{Co}^{2+}$ & $\begin{array}{l}\text { Kation niklu }\left(\mathrm{Ni}^{2+}\right) \\
\text { Kation kobaltu }\left(\mathrm{Co}^{2+}\right)\end{array}$ & 491 & [57] \\
\hline 40 & & $\mathrm{~F}^{-}$ & Anion fluoru (F-) & 2583 & {$[58]$} \\
\hline 41 & & $\mathrm{Mn}^{2+}$ & Kation manganu (Mn2+) & 4383 & {$[55]$} \\
\hline 42 & \multirow{5}{*}{ Inne metabolity } & $\operatorname{glmS}$ & Glukozamino-6-fosforan (GlcN-6-P) & 2126 & [59] \\
\hline 43 & & Azaaromatyczny & Związki azaaromatyczne & 743 & [60] \\
\hline 44 & & Guanidynowy-I & Guanidyna & 867 & {$[61]$} \\
\hline 45 & & Guanidynowy-II & Guanidyna & 610 & [62] \\
\hline 46 & & Guanidynowy-III & Guanidyna & 237 & [63] \\
\hline
\end{tabular}

(np. Arabidopsis thaliana, Oryza sativa, Pinus taeda), cztery u alg (np. Chlamydomonas reinhardtii) i siedem u Protista Perkinsus marinus. Uważa się, że ryboprzełączniki nie występują $\mathrm{w}$ królestwie zwierząt. Jedynym jak dotąd znanym wyjątkiem to pojedyncza kopia ryboprzełącznika TPP u stułbi Hydra magnipapillata. Ponadto pojedyncze kopie ryboprzełącznika wiążącego cykliczne cząsteczki c-di-GMP-I [40] oraz aminokwas glutaminę wykryto $\mathrm{w}$ genomach wirusowych [24]. Uważa się, że około $4 \%$ genów i operonów bakteryjnych może być kontrolowanych za pośrednictwem ryboprzełączników [65].

Jak dotąd nie są znane żadne ryboprzełączniki występujące u człowieka, chociaż zidentyfikowano sekwencje
RNA zdolne do binarnej zmiany swojej struktury pod wpływem bodźców zewnętrznych. Przykładem takie regulatorowego RNA jest sekwencja zlokalizowana w 3'UTR transkryptu czynnika wzrostu śródbłonka naczyniowego A (VEGF, ang. vascular endothelial growth factor) w komórkach szpiku, który reaguje na stres hipoksji oraz interferon y za pośrednictwem białek odpowiednio hnRNP (ang. heterogenous nuclear ribonucleoprotein $L$ ) oraz kompleks GAIT (ang. IFN- $\gamma$-activated inhibitor of translation) [66]. W normalnych warunkach białko hnRNP L ulega degradacji, co umożliwia kompleksowi GAIT przyłączenie się do struktury RNA i blokowanie translacji. Natomiast $\mathrm{w}$ warunkach hipoksji białko hnRNP L pozostaje na wysokim poziomie i samo wiąże się do 3'UTR, wy- 


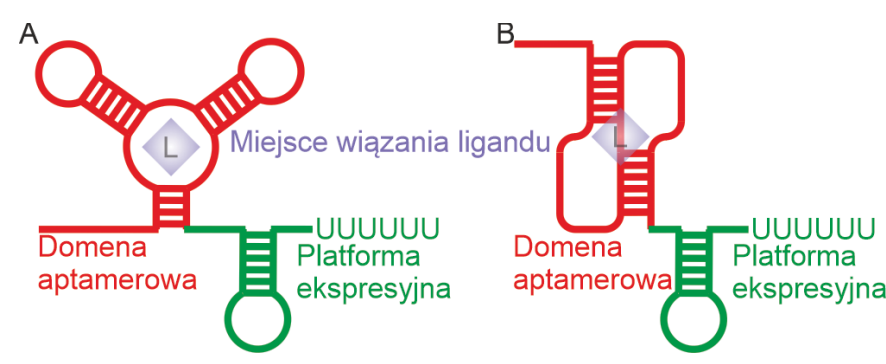

Rycina 1. Budowa ryboprzełączników. (A) Ryboprzełączniki z pętlą centralną. (B) Ryboprzełączniki pseudowęzłowe. L - ligand.

kluczając oddziaływanie z kompleksem GAIT. I chociaż zmiana struktury pod wpływem związków chemicznych jest analogiczna jak w przypadku ryboprzełączników (podobnie jak efekt regulatorowy), to jednak zachodzi on w sposób niezależny od stężenia metabolitu będącego rezultatem ekspresji kontrolowanego mRNA, a w odpowiedzi na sygnały pochodzące $\mathrm{z}$ zewnątrz pośredniczą białka.

\section{STRUKTURA RYBOPRZEŁĄCZNIKÓW}

We wszystkich ryboprzełącznikach możemy wyróżnić dwie funkcjonalnie i strukturalnie odrębne domeny: domenę aptamerową i platformę ekspresyjną (Ryc. 1). Pierwsza z nich jest odpowiedzialna za bezpośrednie interakcje z ligandem. Ze względu na pełnione przez nią funkcje (wiązanie danego metabolitu i jednocześnie dyskryminację pomiędzy podobnymi cząsteczkami), domena ta jest ewolucyjnie zakonserwowana, a zwłaszcza miejsca bezpośredniego oddziaływania z ligandem. W wyniku związania ligandu zmianie konformacyjnej ulega druga, znacznie słabiej zakonserwowana ewolucyjnie część ryboprzełącznika - platforma ekspresyjna, odpowiedzialna za efekt regulatorowy genu, w którym się znajduje.

Ze względu na dominującą strukturę drugorzędową domeny aptamerowej ryboprzełączniki dzielimy na dwa rodzaje: łącznikowe, z pętlą centralną (ang. junctional) (Ryc. 1A) oraz pseudowęzłowe (ang. pseudoknoted) (Ryc. 1B). Pierwsze z nich są zbudowane $z$ centralnie położonej pętli, od której promieniście rozchodzą się dwuniciowe struktury spinek do włosów. Liczba spinek może się wahać od dwóch dla ryboprzełącznika adeninowego [48] do sześciu dla ryboprzełącznika FMN [67] Pewne ryboprzełączniki przyjmują alternatywną architekturę, w której pętla centralna jest położona peryferyjnie, a z helisą P1 oddziałuje przez oddalone elementy struktury trzeciorzędowej, czego przykładem może być ryboprzełącznik wiążący THF [68]. Ryboprzełączniki pseudowęzłowe charakteryzują się występowaniem dominującej struktury pseudowęzła tj. struktury, gdzie pętla pierwszej spinki RNA paruje się z ramieniem spinki drugiej, natomiast pętla drugiej spinki $\mathrm{z}$ ramieniem pierwszej. Przykładem takiego ryboprzełącznika jest SAM-II [69].

Poszczególne elementy struktury drugorzędowej, takie jak spinki do włosów, pseudowęzły, czy struktury typu kissing-loop tworzą kieszeń wiążącą, ściśle dopasowaną do konkretnego ligandu, co zapewnia wysoką specyficzność i powinowactwo. Miejsce wiązania ligandu najczęściej zlokalizowane jest w pobliżu pętli centralnej lub w środku pseudowęzła. Aptamery ryboprzełączników mogą bardzo istotnie różnić się wielkością. Najmniejszy znany ryboprzełącznik należy do klasy preQ ${ }_{1}-\mathrm{I}$, zbudowany jest z zaledwie jednej krótkiej spinki tworzącej pseudowęzeł typu H o długości 34 nt [50]. Największe ryboprzełączniki, takie jak lizynowe [70] czy AdoCbl [71], mogą mieć długość ponad $200 \mathrm{nt}$.

Ryboprzełączniki charakteryzują się bardzo wysokim stopniem specyficzności względem ligandu i potrafią rozróżniać nawet bardzo podobne chemicznie i strukturalnie metabolity. I tak na przykład ryboprzełączniki SAM wiążą ligand ze 100- do 1000-krotnie większym powinowactwem w porównaniu do SAH, która różni się od SAM jedynie brakiem jednej grupy metylowej [72]. Ryboprzełącznik SAH z kolei, wiąże SAH z 1000-krotnie większą skutecznością niż cząsteczkę SAM [33]. Jest to bardzo istotne $\mathrm{w}$ tej sytuacji, bowiem w normalnych warunkach komórkowe stężenie SAM jest znacznie większe niż SAH, co w przypadku niższego powinowactwa mogłoby skutkować deregulacją metabolizmu metioniny. Ryboprzełączniki wykazują bardzo wysokie powinowactwo do swojego natywnego metabolitu. Stała wiązania $\left(K_{\mathrm{d}}\right)$ większości ryboprzełączników zazwyczaj wykazuje wartości rzędu nM. Jednak w szczególnych przypadkach $K_{\mathrm{d}}$ ryboprzełączników może przyjmować bardzo niskie wartości wynoszące zaledwie 10 pM (np. ryboprzełącznik c-di-GMP-I u Vibro cholerae) [73], po tak wysokie wartości jak $200 \mu \mathrm{M}$ (ryboprzełącznika GlcN-6-P) [59].

Wysoki stopień specyficzności jest realizowany z wykorzystaniem różnych strategii. Najprostszą z nich jest dopasowanie kształtu i rozmiaru kieszeni wiążącej do konkretnego ligandu. Ryboprzełącznik glicynowy na przykład formuje tak małą kieszeń wiążącą, że żaden inny aminokwas się nie zmieści w jej wnętrzu, z drugiej strony kieszeń ryboprzełącznika lizynowego naśladuje wydłużony kształt lizyny i choć mniejsze ligandy mieszczą się w kieszeni wiążącej, to nie mogą zrealizować wszystkich oddziaływań niezbędnych do przełączenia struktury RNA [74].

W przypadku białek dla poprawnego wiązania ligand-kieszeń wiążąca bardzo istotne są oddziaływania hydrofobowe, bowiem wiele aminokwasów ma właśnie takie własności. Jednak w przeciwieństwie do białek, RNA zawiera wiele heteroatomów zdolnych do oddziaływań elektrostatycznych czy wodorowych, co sprawia, że udział oddziaływań hydrofobowych jest znikomy. Istotnym jest natomiast fakt, że większość ligandów również zawiera heteroatomy. Dlatego też ligandy oddziałują z aptamerem poprzez kilka typów oddziaływań, takich jak oddziaływania elektrostatyczne, van der Waalsa, warstwowe, oddziaływania jon-dipol i wiązania wodorowe. Nie bez znaczenia jest fakt, że duża część ligandów to pochodne RNA, których zasady azotowe chętnie tworzą wiązania wodorowe z innymi nukleotydami [75]. 
Ważną kwestią jest rozpoznawanie ujemnie bądź dodatnio naładowanych cząsteczek ligandów. Wiele ligandów zawiera ujemnie naładowane grupy karboksylowe i fosforanowe (TPP, FMN, c-di-GMP). Aby było możliwe skuteczne oddziaływanie z RNA, ładunek ten musi być zneutralizowany. Najczęściej do tego celu wykorzystywany jest kation $\mathrm{Mg}^{2+}$, który to pośredniczy w oddziaływaniach ligand-aptamer, zarówno bezpośrednio, jak i za pośrednictwem cząsteczek wody [75]. Jony $\mathrm{Mg}^{2+}$ są także istotne dla poprawnego sfałdowania samej struktury ryboprzełącznika oraz zapewnienia stabilności motywów tworzących kieszeń wiążącą. W niektórych przypadkach $\mathrm{Mg}^{2+}$ jest niezbędnym elementem dla poprawnego uformowania się aptameru i pełnienia funkcji regulatorowych. $\mathrm{W}$ innych przypadkach $\mathrm{Mg}^{2+}$ jedynie wspierają poprawnie sfałdowanie ryboprzełącznika, przesuwając równowagę $\mathrm{w}$ kierunku stanu holo (przy podwyższonym stężeniu $\mathrm{Mg}^{2+}$ wystarczą niższe stężenia ligandu by uzyskać efekt regulatorowy). Innymi wykorzystywanymi przez ryboprzełączniki jonami mogą być: $\mathrm{Mn}^{2+}, \mathrm{Ca}^{2+}, \mathrm{Ba}^{2+}$, $\mathrm{Na}^{+}, \mathrm{K}^{+}$. O ile w niektórych przypadkach różne jony mogą pełnić swoją funkcję zamiennie, to niektóre ryboprzełączniki wymagają konkretnego jonu, jak na przykład $\mathrm{K}^{+}$dla ryboprzełącznika lizynowego [74]. Dodatnio naładowane fragmenty ligandów stanowią bardzo istotną, charakterystyczną cechę, specyficznie rozpoznawaną przez poszczególne ryboprzełączniki. Dodatnio naładowany łańcuch boczny lizyny dopasowuje się do negatywnie naładowanego fragmentu kieszeni wiążącej, natomiast grupa metylowa połączona $\mathrm{z}$ atomem siarki nadaje ładunek dodatni cząsteczce SAM, co jest podstawą dyskryminacji pomiędzy SAM i SAH.

Choć w znakomitej większości pojedyncze aptamery wiążą jedną cząsteczkę ligandu, to istnieją także istotne wyjątki od tej reguły. Dotyczy to zwłaszcza niewielkich ligandów, takich jak jony nieorganiczne $\left(\mathrm{Mg}^{2+} \mathrm{lub} \mathrm{NiCo}\right)$, THF czy guanidyna. Badania strukturalne wykazały między innymi, że ryboprzełącznik magnezowy wiąże przynajmniej osiem jonów $\mathrm{Mg}^{2+}$, skoncentrowanych $\mathrm{w}$ trzech skupiskach, natomiast aptamer NiCo wiąże cztery jony w jednej kieszeni wiążącej $[57,76]$. Ryboprzełączniki THF i guanidynowy-II, jako że ich ligandy są większe niż jony metali, zawierają dwie kieszenie wiążące metabolit $[68,77]$. Podejrzewa się, że wiązanie wielu pozwala na kooperatywne działanie ryboprzełącznika [78].

\section{MECHANIZM DZIAŁANIA RYBOPRZEŁĄCZNIKÓW}

Większość ryboprzełączników działa na zasadzie sprzężeń zwrotnych ujemnych, tj. w wyniku ekspresji danego mRNA powstaje metabolit (bądź jest aktywnie importowany do wnętrza komórki), który to po osiągnięciu stężenia granicznego zaczyna oddziaływać z domeną aptamerową, co prowadzi do wyciszenia ekspresji tego mRNA (Ryc. 2). W konsekwencji prowadzi to do stabilizacji stężenia tego metabolitu w komórce na optymalnym poziomie. Tego typu szlak regulatorowy jest charakterystyczny dla genów odpowiedzialnych za import, biosyntezę lub metabolizm niezbędnych cząsteczek. Natomiast pozytywna regulacja z udziałem ryboprzełączników wy-

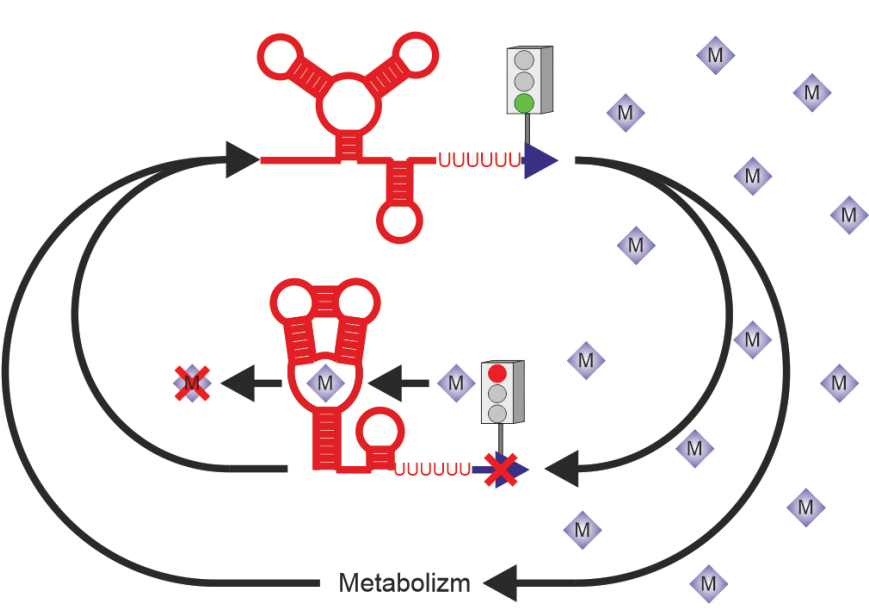

Rycina 2. Sprzężenia zwrotne ujemne z udziałem ryboprzełączników. M - metabolit (ligand).

stępuje rzadziej i charakteryzuje geny zaangażowane w degradację lub eksport nadmiernych lub toksycznych związków chemicznych.

\section{RYBOPRZEŁĄCZNIKI PROKARIOTYCZNE}

Najbardziej rozpowszechnionym mechanizmem regulacji ekspresji genów przez ryboprzełączniki u prokariotów jest przedwczesna terminacja transkrypcji. Ryboprzełącznik po związaniu ligandu (forma holo) przyjmuje alternatywną strukturę spinki terminacyjnej, po której następuje trakt poli-U. W konsekwencji, transkrypcja zostaje przedwcześnie zahamowana i zamiast pełnej długości funkcjonalnego transkryptu powstaje produkt skrócony (Ryc. 3). Obok klasycznej, wewnętrznej terminacji transkrypcji ryboprzełączniki niekiedy wykorzystują także Rho-zależną terminację. Za przykład może posłużyć gen ribB u $E$. coli kontrolowany przez ryboprzełącznik FMN. Związanie ligandu powoduje uwolnienie miejsca

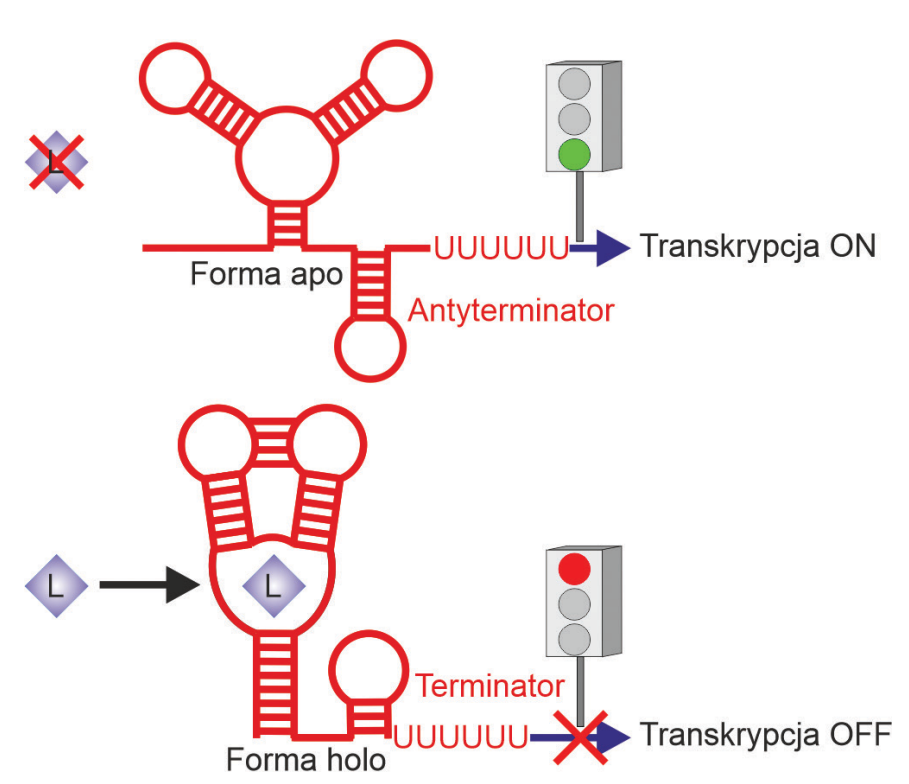

Rycina 3. Mechanizm działania ryboprzełączników transkrypcyjnych. L - ligand. 

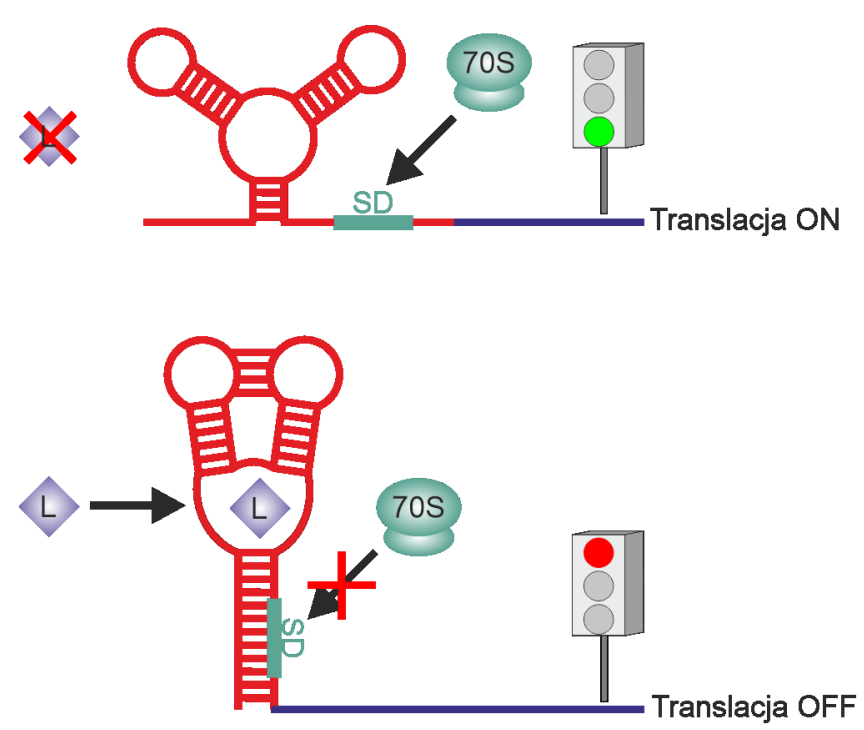

Rycina 4. Mechanizm działania ryboprzełączników translacyjnych. L - ligand, $70 S$ - rybosom bakteryjny, SD - sekwencja Shine-Dalgarno.

wiązania białka Rho, które przemieszczając się wzdłuż nici RNA napotyka RNAP uwalniając niekompletny transkrypt [79].

Innym częstym mechanizmem kontroli ekspresji genów zależnym od ryboprzełączników jest kontrola translacji. W tym wypadku po przyłączeniu ligandu sekwencja Shine-Dalgarno (SD) ulega uwolnieniu bądź sekwestracji w strukturze dwuniciowej, przez co staje się dostępna/niedostępna dla aparatu translacyjnego komórki (Ryc. 4). Przykładem może być pierwszy odkryty ryboprzełącznik AdoCbl zlokalizowany w sekwencji liderowej mRNA btuB u E.coli kodującej białko transportera witaminy B12. Związanie AdoCbl przed domenę aptamerową powoduje wyciszenie ekspresji tego genu, czyniąc sekwencję SD niedostępną dla rybosomów [13]. Zdarza się, że ten sam ryboprzełącznik, kontrolujący ten sam gen $\mathrm{u}$ jednej bakterii kontroluje jego ekspresję przez terminację transkrypcji (B. subtilis) a u innego translację oraz stabilność mRNA (E. coli) [70].

Zupełnie inny mechanizm kontroli ekspresji jest wykorzystywany przez ryboprzełącznik wiążący glukozamino-6-fosforan (GlcN-6-P) zlokalizowany w genie glmS u B. subtilis kodującego aminotransferazę GlcN-6-P [59]. Funkcjonuje on jednocześnie jako ryboprzełącznik oraz rybozym, przeprowadzający autokatalityczne cięcie własnej cząsteczki, wykorzystując ligand GlcN-6P jako katalizator. Taki przecięty produkt ulega następnie szybkiej degradacji przez RNazę J. Inne katalityczne ryboprzełączniki po związaniu danego metabolitu przeprowadzają reakcję alternatywnego wycinania intronów w pre-mRNA, przez co $\mathrm{z}$ transkryptu zostaje usunięta sekwencja RBS [70].

Ryboprzełączniki mogą także kontrolować splicing. $\mathrm{U}$ bakterii Clostridium difficile samowycinający się intron grupy I jest sprzężony z ryboprzełącznikiem wiążącym cząsteczkę sygnałową cykliczny diguanozynomonofosforan (c-di-GMP) [41]. W formie apo zachodzi wycięcie intronu z użyciem dystalnego miejsca splicingowego, czego rezul- tatem jest skrócony transkrypt z niekompletnym miejscem SD. Natomiast $\mathrm{w}$ formie holo, preferowane jest proksymalne miejsce splicingowe połączone z jednoczesnym samowycięciem się krótkiego intronu w taki sposób, że dwie części rozdzielonego wcześniej intronu zostają połączone, co umożliwia powstanie miejsca SD i zajście prawidłowej translacji.

Choć zdecydowana większość ryboprzełączników działa w układzie cis, w wyjątkowych przypadkach mogą regulować ekspresję genów w układzie trans. U bakterii Listeria monocytogenes dwa geny metabolizmu siarki: sreA i sreB są kontrolowane ryboprzełącznikiem SAM, gdzie w obecności ligandu transkrypt ulega przedwczesnej terminacji [80]. Jak się okazało, te skrócone transkrypty są w dużej mierze komplementarne do sekwencji mRNA genu prfA i mogą funkcjonować w sposób analogiczny do sRNA (poprzez interakcje sens-antysens). Takie bezpośrednie oddziaływanie prowadzi do wyciszenia ekspresji prfA, który to pełni zróżnicowane funkcje związane $\mathrm{z}$ wirulencją bakterii. Takie powiązanie stężenia SAM w komórce $\mathrm{z}$ wirulencją ma istotne znaczenie dla L. monocytogenes, jako bakterii patogennej. Podwyższone stężenie SAM jest sygnałem, że bakteria znalazła się w środowisku obfitującym w składniki odżywcze ergo w organizmie człowieka, co stanowi dogodne warunki i może aktywować ekspresję genów wirulencji.

\section{RYBOPRZEŁĄCZNIKI EUKARIOTYCZNE}

Na szczególna uwagę zasługuje jedna klasa ryboprzełączników - TPP, której występowanie nie ogranicza się jedynie do domeny Prokaryota. Występuje ona także u eukariotów, takich jak rośliny czy grzyby, a nawet zwierząt niższych. Jak dotąd żadne badania nie potwierdziły obecności ryboprzełączników w genomach zwierząt wyższych, w tym ludzi [81]. Grupa eukariotycznych ryboprzełączników TPP posiada kilka unikatowych cech. W przeciwieństwie do bakteryjnych ryboprzełączników, te eukariotyczne nie występują tylko w 5'UTR, ale także w intronach ORF (u grzybów i zielenic) lub w 3’UTR (rośliny wyższe). Ponadto zamiast kontroli transkrypcji lub translacji, swoje funkcje regulatorowe $\mathrm{w}$ komórce pełnią poprzez alternatywny splicing.

U grzybów, m. in. Neurospora crassa, transkrypt genu NMT1 posiada kilka różnych ramek odczytu [82]. W warunkach niskiego stężenia TPP wycięciu ulega niefunkcjonalna uORF (ang. upstream ORF), dlatego też może dojść do prawidłowej ekspresji kompletnej ORF tego genu (alternatywne miejsca splicingowe pozostają ukryte). Natomiast w sytuacji, kiedy TPP jest w komórce obecny, zmiana struktury ryboprzełącznika odblokowuje alternatywne miejsca splicingowe, które są preferencyjnie wybierane przez splicesom, czego skutkiem jest transkrypcja wyłącznie niefunkcjonalne uORF.

U roślin niższych, takich jak zielenice Chlamydomonas reinhardtii, ryboprzełącznik TPP kontrolujący ekspresję genu THIC znajduje jest w intronie zlokalizowanym w ORF [83]. W środowisku niskiego stężenia TPP wycięciu ulega cały intron wraz z sekwencją ryboprzełącznika. Po związaniu TPP przez ryboprzełącznik ujawniają się dwa alternatywne miejsca splicingowe, co skutkuje retencją fragmentu intronu 

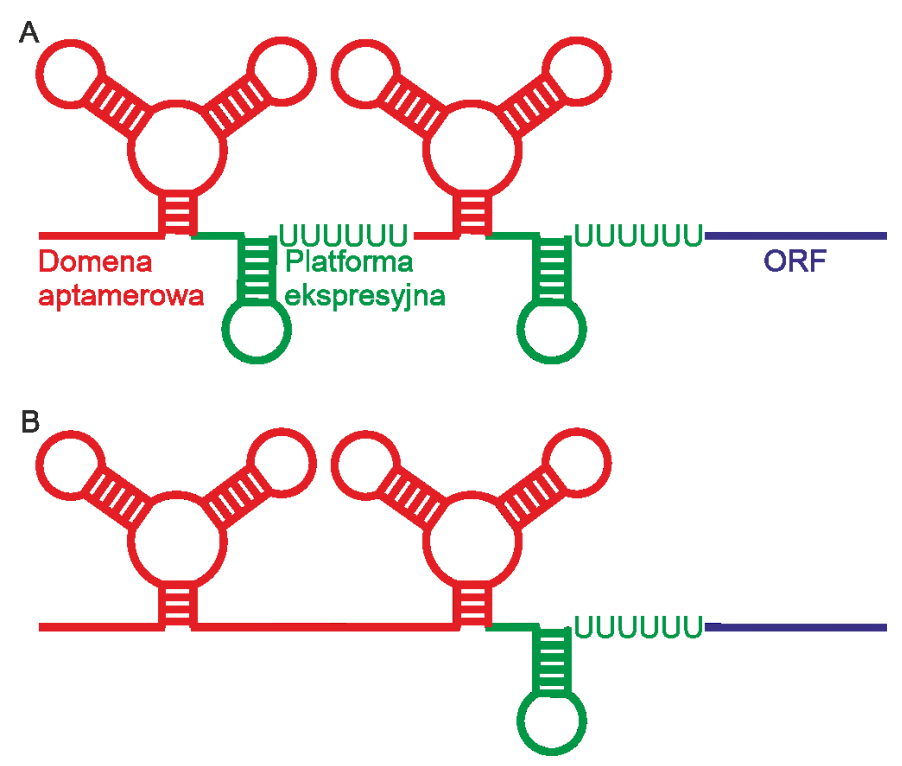

Rycina 5. Ryboprzełączniki tandemowe. (A) Dwa niezależne ryboprzełączniki poprzedzające wspólny ORF. (B) Dwie domeny aptamerowe poprzedzające wspólną platformę ekspresyjną. ORF - otwarta ranka odczytu.

wraz z przedwczesnym kodonem stop, skutkującym biosyntezą niekompletnego i niefunkcjonalnego białka.

$\mathrm{Z}$ kolei u roślin wyższych, takich jak Arabidopsis thalia$n a$, ryboprzełącznik TPP genu THIC jest umiejscowiony $\mathrm{w}$ 3'UTR [84]. W warunkach niskiego stężenia TPP miejsce splicingowe pozostaje zamknięte w strukturze dwuniciowej i niedostępne dla splicesomu, dlatego też powstały transkrypt posiada krótki 3'UTR wraz z sygnałem poliadenylacji (poli-A), zapewniający stabilność mRNA. W obecności TPP natomiast, miejsce splicingowe zostaje odsłonięte, co skutkuje usunięciem sygnału poli-A. Taki transkrypt charakteryzuje się zwiększoną podatnością na degradację i zmniejszoną stabilność, przekładając się bezpośrednio na obniżoną produkcję białka. Badania wykazały, że transkrypty z długim 3'UTR, dodatkowo pozbawionym ochronnych właściwości ogona poli-A, są potencjalnym celem dla NMD (ang. nonsense-mediated decay) [85].

\section{RYBOPRZEŁĄCZNIKI TANDEMOWE}

Ryboprzełączniki mogą także funkcjonować w bardziej skomplikowanych podwójnych układach, jako ryboprzełączniki tandemowe, stanowiące wyrafinowane bramki logiczne. Funkcją takiego rozwiązania ryboprzełączników jest ściślejsza kontrola ekspresji, większy zakres dynamiczny (ang. dynamic range) lub zmiana/rozbudowa specyficzności.

W układzie tandemowym mogą także występować całe ryboprzełączniki (dwa aptamery wraz z dwiema platformami ekspresyjnymi), jak to ma miejsce $\mathrm{w}$ przypadku ryboprzełączników TPP kontrolujących gen tenA u Bacillus anthracis (Ryc. 5A) [15]. W tym wypadku dopiero związanie obu aptamerów skutkuje wyłączeniem ekspresji tenA. Z kolei ryboprzełącznik glicynowy u $B$. subtilis (ale także u wielu innych bakterii), kontrolujący ekspresję operonu gcvT, skła- da się z dwóch domen aptamerowych, po których występuje wspólna platforma ekspresyjna (Ryc. 5B) [46].

\section{PRAKTYCZNE ZASTOSOWANIE RYBOPRZEŁĄCZNIKÓW}

\section{CEL ANTYBIOTYKOTERAPII}

Najistotniejszą cechą ryboprzełączników w kontekście antybiotykoterapii jest fakt, iż kontrolują kluczowe dla przeżycia bakterii szlaki metaboliczne [86]. Jednocześnie, mogą być z łatwością zablokowane przez podanie analogów ich natywnych ligandów, które wiążą ryboprzełącznik i wyciszają ekspresję kontrolowanych genów, same natomiast nie są metabolicznie funkcjonalne. Ważną cechą takiego podejścia jest bezpieczeństwo, nie są bowiem jak dotąd poznane żadne ryboprzełączniki występujące u ludzi. Wiele badań w tej dziedzinie przeprowadzono dla ryboprzełącznika wiążącego FMN. Kontroluje on geny biosyntezy i transportu ryboflawiny. FMN stanowi grupe prostetyczną wielu enzymów uczestniczących $\mathrm{w}$ reakcjach redoks. rozeoflawina (RoF), wytwarzana przez Streptomyces davawensis jest jedynym znanym naturalnym antybiotykiem wycelowanym $\mathrm{w}$ ryboprzełącznik [87]. Zaprojektowano inny analog ryboflawiny o lepszych właściwościach antybiotykowych i mniejszej toksyczności, nakierowany na ryboprzełącznik FMN, nazwany 5FDQD [88]. Badania wskazują, że właściwości 5FDQD takie jak $\mathrm{K}_{\mathrm{d}^{\prime}}$ okres półtrwania czy sposób wiązania się do ryboprzełącznika są bardzo podobne do FMN [88]. Właściwości antybakteryjne 5FDQD są porównywalne z wankomycyną, a jednocześnie analizy wykazały, że efekt ten jest uzyskiwany szybciej.

Inny związek o właściwościach bakteriobójczych, którego celem molekularnym jest ryboprzełącznik, Ribocil, zsyntetyzowany został przez firmę Merck \& Co [89]. Ribocil wiąże się do ryboprzełącznika FMN genu ribB z wysokim powinowactwem wynoszącym 6,6 $\mathrm{nM}$ (dla natywnego metabolitu FMN $K_{d}$ wynosi 1,2 nM). Gen ribB jest zaangażowany w biosyntezę ryboflawiny, kofaktora niezbędnego dla przeżycia bakterii. $\mathrm{W}$ testach in vitro stężenie Ribocil inhibujące wzrost $E$. coli $\left(\mathrm{IC}_{50}\right)$ wynosiło $0,3 \mu \mathrm{M}$, natomiast MIC (ang. minimum inhibitory concentration) wynosił $2 \mu \mathrm{g} / \mathrm{ml}$. Właściwości przeciwbakteryjne zostały wykazane także dla innych patogennych bakterii, takich jak Pseudomonas aeruginosa czy Acinetobacter baumannii oraz odporne na metycylinę szczepy Staphylococcus aureus (MRSA, ang. methicyllin-resistant Staphylococcus aureus), Enterococcus faecalis czy Streptococcus pyogenes [90].

\section{RYBOSELEKTORY}

Syntetyczne układy ryboprzełączników wraz z odpowiednio dobraną sekwencją kodującą czynnik selekcyjny pozwalają na stworzenie samopolepszającego się układu do produkcji różnego rodzaju metabolitów czy bioproduktów. Tego typu „biologiczne urządenie” nazywamy ryboselektorem (ang. riboselector) [91]. Ryboselektor składa się z dwóch modułów: ryboprzełącznika i genu stanowiącego czynnik selekcyjny. Ryboselektory pozwalają na skuteczną optymalizację szlaków metabolicznych poprzez łączenie wewnątrzkomórkowego stężenia określonego metabolitu 
z przeżyciem komórki pod presją selekcyjną. Ryboselektor opracowany przez Yang i współpracowników składał się z represyjnego ryboprzełącznika lizynowego genu lys C E. coli i markera selekcyjnego tet $A$, zapewniającego jednocześnie odporność na działanie tetracykliny i wrażliwość na toksyczny $\mathrm{NiCl}_{2}[92]$.

\section{RYBOSENSORY}

Biosensor jest urządzeniem analitycznym służącym do wykrywania analitu, które łączy składnik biologiczny z detektorem fizykochemicznym. Istnieje wiele różnorodnych związków biologicznych wykorzystywanych jako elementy rozpoznania, $\mathrm{w}$ tym: enzymy, przeciwciała, receptory, RNA, DNA, organelle, tkanki i całe komórki [93]. Rozpoznanie danej cząsteczki zazwyczaj wyzwala uwolnienie sygnału elektrochemicznego lub optycznego zebranego i skwantyfikowanego przez detektor. W 2009 opracowano biosensor wykrywający teofilinę, lek przeciwastmatyczny, którego przedawkowanie może mieć poważne konsekwencje zdrowotne, jak napady padaczki czy zaburzenia rytmu serca. Biosensor ten składał się z domeny aptamerowej wiążącej teofilinę jako czujnik połączonej z końcem 5' sekwencji kodującej GFP, białka zdolnego do emisji sygnału świetlnego (ang. green fluorescence protein) [94]. Badania wykazały, że w obecności teofiliny ów biosensor podowuje zależne od dawki wyciszenie ekspresji GFP, osiągając pięciokrotny spadek sygnału przy $1 \mathrm{mM}$ stężeniu teofiliny.

Inne podejście zaprezentowali naukowcy z Cornell University w Nowym Jorku [95]. Domeny aptamerowe różnych ryboprzełaączników (TPP, andeninowy, guaninowy, SAM) sprzężono z 84-nukleotydowym aptamerem Spinach, który strukturalnie imituje białko GFP [96], co pozwala na równie wydajnie wiązanie fluoroforów podobnych do tych natywnie wiązanych przez GFP, takich jak DFHBI. Tego typu fluorofory wykazują właściwości fuorescencyjne tylko po związaniu przez aptamer Spinach. Przyłączenie odpowiedniego ligandu powoduje emisję sygnału świetlnego. Uzyskany konstrukt charakteryzuje się zbliżoną specyficznością i powinowactwem jak naturalny ryboprzełacznik TPP o $\mathrm{EC}_{50}$ równym $9 \mu \mathrm{M}$ oraz $K_{\mathrm{d}}$ równym $600 \mathrm{nM}$. Cały konstrukt osiągną wysoką wydajnością i czułość, powodując 16-krotny wzrost fluorescencji przy komórkowym stężeniu TPP $100 \mu \mathrm{M}$.

\section{INDUKOWALNE UKŁADY KONTROLI EKSPRESJI}

Opracowano nowe oraz zoptymalizowano dotychczasowe synteteczne aptamery: teofilinowy, tetrametylorodaminowy, dopaminowy, tyroksynowy, 2,4-dinitrotoluenowy. Metodami inżynierii genetycznej udalo się stworzyć indukowany układ kontroli ekspresji genów u drożdzy Saccharomyces cerevisiae. Z wykorzystaniem aptamerów tetracyklinowych i neomycynowych kontrolujących skanowanie rybosomu udało się osiągnąć poziom indukcji odpowiednio sześcio- i siedmiokrotnym [97,98]. Podobne układy udało się stworzyć także w organizmach roślinnych [99] i wirusowych [100].
GENETYCZNIE MODYFIKOWANE WIRUSY ONKOLITYCZNE

Badacze z zespołu Nettelbeck'a z Niemieckiego Centrum Badań nad Rakiem w Heidelbergu zaprojektowali dwa genetycznie zmodyfikowane onkolityczne wirusy: adenowirus $(\mathrm{AdV})$ i wirus odry $(\mathrm{MeV})$, których geny znajdują się pod kontrolą ryboprzełącznika wiążącego teofilinę [100]. Konstrukty te powstały przez połaczenie dwóch ryboprzełączników o właściwościach autokatalitycznych, umieszczonych na końcu 5' i 3' odpowiednich genów (E1A u AdV i glikoproteiny $\mathrm{F} \mathrm{u} \mathrm{MeV).} \mathrm{W} \mathrm{warun-}$ kach normalnych geny ulegają ekspresji, a replikacja i infekcyjność wirusa pozostaje bez zmian. Natomiast po dodaniu do środowiska teofiliny ryboprzełącznik ulega aktywacji, a z transkryptu zostaje wycięty odpowiedni ORF. Badania wykonane na AdV wykazały 200-krotnie obniżoną produkcję białka E1A. Eksperyment przeprowadzony z użyciem komórek SK-MEL-28 (komórki czerniaka złośliwego) wykazał dużą skuteczność antynowotworową wirusa (przeżywalność komórek wynosiła $10 \%$ ). Jednocześnie, po podaniu teofiliny przeżywalność wzrastała do $80 \%$, w sposób zależny od dawki. Zmodyfikowany MeV także wykazywał skuteczne działanie in vivo $\mathrm{w}$ odpowiedzi na teofilinę, powodując 11- i 6-krotny spadek produkcji wirionów, odpowiednio w Verocells i SK-MEL-28.

\section{PODSUMOWANIE}

Przez blisko 20 lat badań nad ryboprzełącznikami przekonaliśmy się, jak ciekawy i różnorodny jest świat ryboprzełączników. Ich reprezentanci występują we wszystkich królestwach życia, od najprostszych baterii po zwierzęta. Były najprawdopodobniej obecne u zarania życia i w niemal niezmienionej formie znajdziemy je także u współczesnych organizmów. Dzięki swojej oszczędnej formie powalają na regulację ekspresji genów w niezwykle prosty sposób, nie tracą przy tym na precyzji i wydajności. 45 dotąd poznanych klas ryboprzełączników rozpoznają szerokie spektrum różnego rodzaju cząsteczek. Zdecydowana większość z nich to niezbędne dla przetrwania komórki metabolity jak pochodne witamin, aminokwasów czy nukleotydów. A ryboprzełączniki pełnią centralną role $\mathrm{w}$ kontroli ich metabolizmu i biosyntezy. Właściwości ryboprzełączników sprawiają, że są one aktualnie obiektem niezwykle interesujących i obiecujących badań, zwłaszcza tych skupionych na ich praktycznym wykorzystaniu.

\section{PIŚMIENNICTWO}

1. Jacob F, Perrin D, Sanchez C, Monod J (1960) Operon: a group of genes with the expression coordinated by an operator. C R Biol 250: 1727-9

2. Gralla J, Steitz JA, Crothers DM (1974) Direct physical evidence for secondary structure in an isolated fragment of R17 bacteriophage mRNA. Nature 248(445): 204-8

3. Yanofsky C (1981) Attenuation in the control of expression of bacterial operons. Nature 289(5800): 751-8

4. Lee F, Squires CL, Squires C, Yanofsky C (1976) Termination of transcription in vitro in the Escherichia coli tryptophan operon leader region. J Mol Biol 103(2): 383-93

5. Bronson MJ, Squires C, Yanofsky C (1973) Nucleotide sequences from tryptophan messenger RNA of Escherichia coli: the sequence corre- 
sponding to the amino-terminal region of the first polypeptide specified by the operon. Proc Natl Acad Sci 70(8): 2335-9

6. Kruger K, Grabowski PJ, Zaug AJ, Sands J, Gottschling DE, Cech TR (1982) Self-splicing RNA: autoexcision and autocyclization of the ribosomal RNA intervening sequence of Tetrahymena. Cell 31(1): 147-57

7. Guerrier-Takada C, Gardiner K, Marsh T, Pace N, Altman S (1983) The RNA moiety of ribonuclease $\mathrm{P}$ is the catalytic subunit of the enzyme. Cell 35(3 Pt 2): 849-57

8. Ellington AD, Szostak JW (1990) In vitro selection of RNA molecules that bind specific ligands. Nature 346(6287): 818-22

9. Tuerk C, Gold L (1990) Systematic evolution of ligands by exponential enrichment: RNA ligands to bacteriophage T4 DNA polymerase. Science 249(4968): 505-10

10. Kadner RJ (1978) Repression of synthesis of the vitamin B12 receptor in Escherichia coli. J Bacteriol 136(3): 1050-7

11. Webb E, Febres F, Downs DM (1996) Thiamine pyrophosphate (TPP) negatively regulates transcription of some thi genes of Salmonella typhimurium. J Bacteriol 178(9): 2533-8

12. Ravnum S, Andersson DI (2001) An adenosyl-cobalamin (coenzyme-B12)-repressed translational enhancer in the cob mRNA of Salmonella typhimurium. Mol Microb 39(6): 1585-94

13. Nahvi A, Sudarsan N, Ebert MS, Zou X, Brown KL, Breaker RR (2002) Genetic control by a metabolite binding mRNA. Chem Biol 9(9):1043

14. Mironov AS, Gusarov I, Rafikov R, Lopez LE, Shatalin K, Kreneva RA, et al. (2002) Sensing small molecules by nascent RNA: a mechanism to control transcription in bacteria. Cell 111(5): 747-56

15. Winkler W, Nahvi A, Breaker RR (2002) Thiamine derivatives bind messenger RNAs directly to regulate bacterial gene expression. Nature 419(6910): 952-6

16. Batey RT, Gilbert SD, Montange RK (2004) Structure of a natural guanine-responsive riboswitch complexed with the metabolite hypoxanthine. Nature 432(7015): 411-5

17. Serganov A, Yuan YR, Pikovskaya O, Polonskaia A, Malinina L, Phan AT, et al. (2004) Structural basis for discriminative regulation of gene expression by adenine- and guanine-sensing mRNAs. Chem Biol 11(12): 1729-41

18. Bock LC, Griffin LC, Latham JA, Vermaas EH, Toole JJ (1992) Selection of single-stranded DNA molecules that bind and inhibit human thrombin. Nature 355(6360): 564-6

19. Miranda-Rios J, Navarro M, Soberon M (2001) A conserved RNA structure (thi box) is involved in regulation of thiamin biosynthetic gene expression in bacteria. Proc Natl Acad Sci 98(17): 9736-41

20. Kil YV, Mironov VN, Gorishin I, Kreneva RA, Perumov DA (1992) Riboflavin operon of Bacillus subtilis: unusual symmetric arrangement of the regulatory region. Mol General Genet 233(3): 483-6

21. Nou X, Kadner RJ (1998) Coupled changes in translation and transcription during cobalamin-dependent regulation of btuB expression in Escherichia coli. J Bacteriol 180(24): 6719-28

22. Gelfand MS, Mironov AA, Jomantas J, Kozlov YI, Perumov DA (1999) A conserved RNA structure element involved in the regulation of bacterial riboflavin synthesis genes. Trends Genet 15(11): 439-42

23. Nou X, Kadner RJ (2000) Adenosylcobalamin inhibits ribosome binding to btuB RNA. Proc Natl Acad Sci 97(13): 7190-5

24. McCown PJ, Corbino KA, Stav S, Sherlock ME, Breaker RR (2017) Riboswitch diversity and distribution. RNA 23(7): 995-1011

25. Nahvi A, Barrick JE, Breaker RR (2004) Coenzyme B12 riboswitches are widespread genetic control elements in prokaryotes. Nucl Acids Res 32(1): 143-50

26. Winkler WC, Nahvi A, Sudarsan N, Barrick JE, Breaker RR (2003) An mRNA structure that controls gene expression by binding S-adenosylmethionine. Nat Struct Biol 10(9): 701-7

27. Weinberg Z, Regulski EE, Hammond MC, Barrick JE, Yao Z, Ruzzo $\mathrm{WL}$, et al. (2008) The aptamer core of SAM-IV riboswitches mimics the ligand-binding site of SAM-I riboswitches. RNA 14(5): 822-8
28. Weinberg Z, Wang JX, Bogue J, Yang J, Corbino K, Moy RH, et al. (2010) Comparative genomics reveals 104 candidate structured RNAs from bacteria, archaea, and their metagenomes. Genom Biol 11(3): R31

29. Tucker BJ, Puskarz I, et al. (2005) Evidence for a second class of S-adenosylmethionine riboswitches and other regulatory RNA motifs in alpha-proteobacteria. Genom Biol 6(8) :R70

30. Poiata E, Meyer MM, Ames TD, Breaker RR (2009) A variant riboswitch aptamer class for S-adenosylmethionine common in marine bacteria. RNA 15(11): 2046-56

31. Fuchs RT, Grundy FJ, Henkin TM (2006) The S(MK) box is a new SAM-binding RNA for translational regulation of SAM synthetase. Nat Struct Mol Biol 13(3): 226-33

32. Mirihana Arachchilage G, Sherlock ME, Weinberg Z, Breaker RR (2018) SAM-VI RNAs selectively bind S-adenosylmethionine and exhibit similarities to SAM-III riboswitches. RNA Biol 15(3): 371-8

33. Wang JX, Lee ER, Morales DR, Lim J, Breaker RR (2008) Riboswitches that sense S-adenosylhomocysteine and activate genes involved in coenzyme recycling. Mol Cell 29(6): 691-702

34. Winkler WC, Cohen-Chalamish S, Breaker RR (2002) An mRNA structure that controls gene expression by binding FMN. Proc Natl Acad Sci 99(25): 15908-13

35. Weinberg Z, Nelson JW, Lunse CE, Sherlock ME, Breaker RR (2017) Bioinformatic analysis of riboswitch structures uncovers variant classes with altered ligand specificity. Proc Natl Acad Sci 114(11): E2077-E85

36. Ames TD, Rodionov DA, Weinberg Z, Breaker RR (2010) A eubacterial riboswitch class that senses the coenzyme tetrahydrofolate. Chem Biol 17(7): 681-5

37. Chen X, Mirihana Arachchilage G, Breaker RR (2019) Biochemical validation of a second class of tetrahydrofolate riboswitches in bacteria. RNA doi: $10.1261 /$ rna.071829.119

38. Regulski EE, Moy RH, Weinberg Z, Barrick JE, Yao Z, Ruzzo WL, et al. (2008) A widespread riboswitch candidate that controls bacterial genes involved in molybdenum cofactor and tungsten cofactor metabolism. Mol Microb 68(4): 918-32

39. Kim PB, Nelson JW, Breaker RR (2015) An ancient riboswitch class in bacteria regulates purine biosynthesis and one-carbon metabolism. Mol Cell 57(2): 317-28

40. Sudarsan N, Lee ER, Weinberg Z, Moy RH, Kim JN, Link KH, et al. (2008) Riboswitches in eubacteria sense the second messenger cyclic di-GMP. Science 321(5887): 411-3

41. Lee ER, Baker JL, Weinberg Z, Sudarsan N, Breaker RR (2010) An allosteric self-splicing ribozyme triggered by a bacterial second messenger. Science 329(5993): 845-8

42. Nelson JW, Sudarsan N, Phillips GE, Stav S, Lunse CE, McCown PJ, et al. (2015) Control of bacterial exoelectrogenesis by c-AMP-GMP. Proc Natl Acad Sci 112(17):5389-94

43. Nelson JW, Sudarsan N, Furukawa K, Weinberg Z, Wang JX, Breaker RR (2013) Riboswitches in eubacteria sense the second messenger c-diAMP. Nat Chem Biol 9(12):834-9

44. Sherlock ME, Sudarsan N, Breaker RR (2018) Riboswitches for the alarmone ppGpp expand the collection of RNA-based signaling systems. Proc Natl Acad Sci 115(23):6052-7

45. Ames TD, Breaker RR (2011) Bacterial aptamers that selectively bind glutamine. RNA Biol 8(1):82-9

46. Mandal M, Lee M, Barrick JE, Weinberg Z, Emilsson GM, Ruzzo WL, et al. (2004) A glycine-dependent riboswitch that uses cooperative binding to control gene expression. Science 306(5694): 275-9

47. Sudarsan N, Wickiser JK, Nakamura S, Ebert MS, Breaker RR (2003) An mRNA structure in bacteria that controls gene expression by binding lysine. Genes Devel 17(21):2688-97

48. Mandal M, Boese B, Barrick JE, Winkler WC, Breaker RR (2003) Riboswitches control fundamental biochemical pathways in Bacillus subtilis and other bacteria. Cell 113(5): 577-86

49. Kim JN, Roth A, Breaker RR (2007) Guanine riboswitch variants from Mesoplasma florum selectively recognize 2 '-deoxyguanosine. Proc Natl Acad Sci 104(41): 16092-7 
50. Roth A, Winkler WC, Regulski EE, Lee BW, Lim J, Jona I, et al. (2007) A riboswitch selective for the queuosine precursor preQ1 contains an unusually small aptamer domain. Nat Struct Mol Biol 14(4): 308-17

51. Meyer MM, Roth A, Chervin SM, Garcia GA, Breaker RR (2008) Confirmation of a second natural preQ1 aptamer class in Streptococcaceae bacteria. RNA 14(4): 685-95

52. McCown PJ, Liang JJ, Weinberg Z, Breaker RR (2014) Structural, functional, and taxonomic diversity of three preQ1 riboswitch classes. Chem Biol 21(7): 880-9

53. Sherlock ME, Sudarsan N, Stav S, Breaker RR (2018) Tandem riboswitches form a natural Boolean logic gate to control purine metabolism in bacteria. eLife doi: 10.7554/eLife.33908

54. Sherlock ME, Sadeeshkumar H, Breaker RR (2019) Variant Bacterial Riboswitches Associated with Nucleotide Hydrolase Genes Sense Nucleoside Diphosphates. Biochemistry 58(5): 401-10

55. Barrick JE, Corbino KA, Winkler WC, Nahvi A, Mandal M, Collins J, et al. (2004) New RNA motifs suggest an expanded scope for riboswitches in bacterial genetic control. Proc Natl Acad Sci 101(17): 6421-6

56. Park SY, Cromie MJ, Lee EJ, Groisman EA (2010) A bacterial mRNA leader that employs different mechanisms to sense disparate intracellular signals. Cell 142(5): 737-48ubMed Central PMCID: PMC2967377.

57. Furukawa K, Ramesh A, Zhou Z, Weinberg Z, Vallery T, Winkler WC, et al. (2015) Bacterial riboswitches cooperatively bind $\mathrm{Ni}(2+)$ or $\mathrm{Co}(2+)$ ions and control expression of heavy metal transporters. Mol Cell 57(6):1088-98

58. Baker JL, Sudarsan N, Weinberg Z, Roth A, Stockbridge RB, Breaker RR (2012) Widespread genetic switches and toxicity resistance proteins for fluoride. Science 335(6065): 233-5

59. Winkler WC, Nahvi A, Roth A, Collins JA, Breaker RR (2004) Control of gene expression by a natural metabolite-responsive ribozyme. Nature 428(6980): 281-6

60. Li S, Hwang XY, Stav S, Breaker RR (2016) The yjdF riboswitch candidate regulates gene expression by binding diverse azaaromatic compounds. RNA 22(4): 530-41

61. Nelson JW, Atilho RM, Sherlock ME, Stockbridge RB, Breaker RR (2017) Metabolism of Free Guanidine in Bacteria Is Regulated by a Widespread Riboswitch Class. Mol Cell 65(2): 220-30

62. Sherlock ME, Malkowski SN, Breaker RR (2017) Biochemical Validation of a Second Guanidine Riboswitch Class in Bacteria. Biochemistry 56(2): 352-8

63. Sherlock ME, Breaker RR (2017) Biochemical Validation of a Third Guanidine Riboswitch Class in Bacteria. Biochemistry 56(2): 359-63

64. Sun EI, Leyn SA, Kazanov MD, Saier MH, Jr., Novichkov PS, Rodionov DA (2013) Comparative genomics of metabolic capacities of regulons controlled by cis-regulatory RNA motifs in bacteria. BMC Genom 14: 597

65. Lunse CE, Schmidt MS, Wittmann V, Mayer G (2011) Carba-sugars activate the glmS-riboswitch of Staphylococcus aureus. ACS Chem Biol 6(7): 675-8

66. Ray PS, Jia J, Yao P, Majumder M, Hatzoglou M, Fox PL (2009) A stress-responsive RNA switch regulates VEGFA expression. Nature 457(7231): 915-9

67. Serganov A, Huang L, Patel DJ (2009) Coenzyme recognition and gene regulation by a flavin mononucleotide riboswitch. Nature $458(7235)$ : 233-7

68. Trausch JJ, Ceres P, Reyes FE, Batey RT (2011) The structure of a tetrahydrofolate-sensing riboswitch reveals two ligand binding sites in a single aptamer. Structure 19(10): 1413-23

69. Gilbert SD, Rambo RP, Van Tyne D, Batey RT (2008) Structure of the SAM-II riboswitch bound to S-adenosylmethionine. Nat Struct Mol Biol 15(2): 177-82

70. Caron MP, Bastet L, Lussier A, Simoneau-Roy M, Masse E, Lafontaine DA (2012) Dual-acting riboswitch control of translation initiation and mRNA decay. Proc Natl Acad Sci 109(50):E3444-53

71. Cheng J, Poduska B, Morton RA, Finan TM (2011) An ABC-type cobalt transport system is essential for growth of Sinorhizobium meliloti at trace metal concentrations. J Bacteriol 193(17): 4405-16
72. Lim J, Winkler WC, Nakamura S, Scott V, Breaker RR (2006) Molecular-recognition characteristics of SAM-binding riboswitches. Angew Chemie 45(6): 964-8

73. Smith KD, Lipchock SV, Ames TD, Wang J, Breaker RR, Strobel S (2009) Structural basis of ligand binding by a c-di-GMP riboswitch. Nat Struct Mol Biol 16(12):1218-23

74. Serganov A, Huang L, Patel DJ (2008) Structural insights into amino acid binding and gene control by a lysine riboswitch. Nature 455(7217): 1263-7

75. Peselis A, Serganov A (2014) Themes and variations in riboswitch structure and function. Biochim Biophys Acta 1839(10): 908-18

76. Dann CE, 3rd, Wakeman CA, Sieling CL, Baker SC, Irnov I, Winkler WC (2007) Structure and mechanism of a metal-sensing regulatory RNA. Cell 130(5): 878-92

77. Huang L, Wang J, Lilley DMJ (2017) The Structure of the Guanidine-II Riboswitch. Cell Chem Biol 24(6):695-702

78. Peselis A, Gao A, Serganov A (2015) Cooperativity, allostery and synergism in ligand binding to riboswitches. Biochimie 117:100-9

79. Hollands K, Proshkin S, Sklyarova S, Epshtein V, Mironov A, Nudler E, et al. (2012) Riboswitch control of Rho-dependent transcription termination. Proc Natl Acad Sci 109(14): 5376-81

80. Loh E, Dussurget O, Gripenland J, Vaitkevicius K, Tiensuu T, Mandin $\mathrm{P}$, et al. (2009) A trans-acting riboswitch controls expression of the virulence regulator PrfA in Listeria monocytogenes. Cell 139(4): 770-9

81. Li S, Breaker RR (2013) Eukaryotic TPP riboswitch regulation of alternative splicing involving long-distance base pairing. Nucl Acids Res 41(5):3 022-31

82. Cheah MT, Wachter A, Sudarsan N, Breaker RR (2007) Control of alternative RNA splicing and gene expression by eukaryotic riboswitches. Nature 447(7143):497-500

83. Croft MT, Moulin M, Webb ME, Smith AG (2007) Thiamine biosynthesis in algae is regulated by riboswitches. Proc Natl Acad Sci 104(52): 20770-5

84. Wachter A, Tunc-Ozdemir M, Grove BC, Green PJ, Shintani DK, Breaker RR (2007) Riboswitch control of gene expression in plants by splicing and alternative $3^{\prime}$ end processing of mRNAs. Plant Cell 19(11): 3437-50

85. Kertesz S, Kerenyi Z, Merai Z, Bartos I, Palfy T, Barta E, et al. (2006) Both introns and long $3^{\prime}$-UTRs operate as cis-acting elements to trigger nonsense-mediated decay in plants. Nucl Acids Res 34(21): 6147-57

86. Blount KF, Breaker RR (2006) Riboswitches as antibacterial drug targets. Nat Biotech 24(12): 1558-64

87. Lee ER, Blount KF, Breaker RR (2009) Roseoflavin is a natural antibacterial compound that binds to FMN riboswitches and regulates gene expression. RNA Biol 6(2): 187-94

88. Blount KF, Megyola C, Plummer M, Osterman D, O'Connell T, Aristoff $P$, et al. (2015) Novel riboswitch-binding flavin analog that protects mice against Clostridium difficile infection without inhibiting cecal flora. Antimicrob Agent Chemother 59(9): 5736-46

89. Howe JA, Wang H, Fischmann TO, Balibar CJ, Xiao L, Galgoci AM, et al. (2015) Selective small-molecule inhibition of an RNA structural element. Nature 526(7575): 672-7

90. Wang H, Mann PA, Xiao L, Gill C, Galgoci AM, Howe JA, et al. (2017) Dual-Targeting Small-Molecule Inhibitors of the Staphylococcus aureus FMN Riboswitch Disrupt Riboflavin Homeostasis in an Infectious Setting. Cell Chem Biol 24(5): 576-88

91. Yang J, Seo SW, Jang S, Shin SI, Lim CH, Roh TY, et al. (2013) Synthetic RNA devices to expedite the evolution of metabolite-producing microbes. Nat Comm 4: 1413

92. Jang S, Yang J, Seo SW, Jung GY (2015) Riboselector: riboswitch-based synthetic selection device to expedite evolution of metabolite-producing microorganisms. Methods Enzymol 550: 341-62

93. Han K, Liang Z, Zhou N (2010) Design strategies for aptamer-based biosensors. Sensors 10(5): 4541-57

94. Jo JJ, Shin JS (2009) Construction of intragenic synthetic riboswitches for detection of a small molecule. Biotech Lett 31(10): 1577-81 
95. You M, Litke JL, Jaffrey SR (2015) Imaging metabolite dynamics in living cells using a Spinach-based riboswitch. Proc Natl Acad Sci 112(21): E2756-65

96. Paige JS, Wu KY, Jaffrey SR (2011) RNA mimics of green fluorescent protein. Science 333(6042): $642-6$

97. Suess B, Hanson S, Berens C, Fink B, Schroeder R, Hillen W (2003) Conditional gene expression by controlling translation with tetracycline-binding aptamers. Nucl Acids Res 31(7): 1853-8

98. Weigand JE, Sanchez M, Gunnesch EB, Zeiher S, Schroeder R, Suess $B$ (2008) Screening for engineered neomycin riboswitches that control translation initiation. RNA14(1): 89-97
99. Verhounig A, Karcher D, Bock R (2010) Inducible gene expression from the plastid genome by a synthetic riboswitch. Proc Natl Acad Sci 107(14): 6204-9

100. Ketzer P, Kaufmann JK, Engelhardt S, Bossow S, von Kalle C, Hartig JS, et al. (2014) Artificial riboswitches for gene expression and replication control of DNA and RNA viruses. Proc Natl Acad Sci 111(5): E554-62

\section{The ample world of riboswitches Piotr Machtel ${ }^{\bigotimes}$}

Institute of Bioorganic Chemistry Polish Academy of Sciences, Poznań, Poland

$\square_{\text {corresponding Author: pmachtel@ibch.poznan.pl }}$

Key words: riboswitches, bacteria, gene expression regulation, transcription

\section{ABSTRACT}

Constantly changing environment requires bacteria to respond quickly and decisively at the cellular level. Notwithstanding, bacteria operate with a limited set of resources restricted to a single cell at their disposal. The natural effect of this state of things for bacteria was a development of a variety of different mechanisms for gene expression control. Among them, riboswitches, defined as sequences present in transcripts with their ability of direct binding low-molecular metabolites and inducing a regulatory response, are considered to be one of the most interesting mechanism of gene regulation. In this publication, there is presented current state of knowledge concerning riboswitches, including such aspects as: mechanisms of action of riboswitches, their structure and diversity as well as their distribution. Furthermore, the history of their discovery at the beginning of the 21 st century, and current research that may find future, practical applications. 